\title{
National Electrical Manufacturers Association
}

National Cancer Institute

\section{Source}

National Cancer Institute. National Electrical Manufacturers Association. NCI Thesaurus.

Code $C 94940$.

A leading trade association in the USA whose members are manufacturers of electro industry products. One of its useful functions is to provide agreed upon standards for equipment including medical devices. 